\title{
Editorial
}

\section{Covid-19 vaccination in 2021 and future challenges}

Rodrigo Feliciano do Carmo ${ }^{1}$

${ }^{1}$ Colegiado de Ciências Farmacêuticas, Universidade Federal do Vale do São Francisco

(UNIVASF), Petrolina, Brasil.

https://doi.org/10.28998/rpss.e02106051
Received in: 13/01/2022
Accepted in: 20/01/2022
Available in: 25/01/2022
Corresponding Author:
Rodrigo Feliciano do Carmo
Email: rodrigo.carmo@univasf.edu.br

The year 2021 was marked by the beginning of the vaccination campaign against Covid-19 in Brazil. On January 17, 2021, the National Health Surveillance Agency (Anvisa) approved the emergency use of the Coronavac (Sinovac/Butantan) and Oxford/Astrazeneca vaccines in Brazil. On the same day, a health professional in the city of São Paulo already received the first dose of the immunization Coronavac, just over a month after the first dose in the world was administered in the United Kingdom with the Pfizer/BioNTech vaccine. Since then, thousands of people around the world have been immunized, which has contributed to the significant reduction in the number of deaths around the globe and the relief of health systems.

Despite the great advances in the vaccination campaign against Covid-19 in Brazil in 2021, ending the year with $67.5 \%$ of the population fully vaccinated (1), the year 2022 begins with an increase in the number of cases and hospitalizations for severe acute respiratory syndrome (SARS) caused by the expansion of the Omicron variant of the new coronavirus and the influenza virus H3N2 (Darwin) in national territory.

In 2021 Brazil faced its worst moment of the pandemic, reaching a peak of 4,000 deaths and more than 90,000 daily cases between April and June (2). The increase in cases coincided with the relaxation of social distancing measures and the circulation of the Gamma variant, with greater transmission capacity and possible association with more severe forms of the disease (3). With the advance of vaccination, the country registered less than 100 deaths and 3,000 cases per day in December (2). Meanwhile, Europe and the United States suffer from another wave of cases and hospitalizations, now caused by the Delta variant and the recently discovered Omicron variant, which has a high transmission capacity even in vaccinated individuals (4).

The spread of the Omicron variant in Brazil, associated to the relaxation of social distancing measures and end of year festivities, in addition to the co-circulation of the H3N2 influenza virus, leads us to believe that the year 2022 will be another challenging year for the Brazilian health system. The moving average of cases in the first weeks of the year already records an increase of more than $600 \%$ of new cases of Covid-19, when compared to the last weeks of December 2021. A recent African study showed that efficacy against hospitalisation was reduced from $93 \%$ in the pre-Omicron period to $70 \%$ in the Omicron period (5). Furthermore, the decrease in vaccine efficacy 6 months after the second dose reinforces the need for booster administration to curb the number of new cases in the country.

Therefore, the loss of effectiveness of the vaccines over time, associated with the emergence of new variants of the virus, leads us to believe that the pandemic is still far from over, and that booster doses of the vaccine with the presence of new variants in its composition will be needed regularly, as happens in vaccination campaigns against influenza virus. For the coming months it is of fundamental importance to monitor the behavior of Covid-19 in the national territory, reinforcing the testing of suspected cases, adopting restrictive measures for agglomerations, and accelerating the application of the booster dose of the vaccine to contain the spread of the virus and avoid a collapse in the health system.

\section{REFERENCES}

1. Guedes ACB, Gama CR, Tiussi ACR. Avaliação nutricional subjetiva do idoso: Avaliação Subjetiva Global (ASG) versus Mini Avaliação Nutricional (MAN). Com Ciências Saúde. 2008; 19(4): 377-84.

2. Paula HAA, Oliveira FCE, São José JFB, Gomide CL, Alfenas RCG. Avaliação do estado nutricional de paciente geriátricos. Rev Bras Nutri Clin [Internet]. 2007, [citado 2020 set 10]; 22(4): 280-5. Dispnível em: https://www.researchgate.net/publication/242749015_Avaliacao_do_ estado nutricional de pacientes geriatricos

3. Instituto Brasileiro de Geografia e Estatística (BR). Projeção da população do Brasil para o período 1980-2050. [Internet]. Rio de Janeiro: IBGE; 2008. [citado 2020 set 10]. Disponível em: https://biblioteca.ibge.gov. $\mathrm{br} / \mathrm{visualizacao/livros/liv41229.pdf}$

4. Araújo AS, Andrade M, Pinto FMAG. Higiene e saúde bucal em idosos na atencão primária. uma revisão sistemática. REAS/EJCH. 2020, (Sup.n.44), e2673. Doi: https://doi.org/10.25248/reas.e2673.2020

5. Morais TMN, Silva A, Avi ALRO, Souza PHR, Knobel E, Camargo LFA. A Importância da Atuação Odontológica em Pacientes Internados em Unidades de Terapias Intensivas. RBTI [Internet]. 2006 [citado 2020 mar 4]; 18(4): 412-7. Disponível em: https://www.scielo.br/pdf/rbti/ v18n4/16.pdf

6. Simões ACA, Carvalho DM. A realidade da saúde bucal do Idoso no sudeste brasileiro. Ciência e Saúde Coletiva [Internet]. 2011 [citado2020 abr 16]; 6(6): 2975-2982. Disponível em: https://www. scielo.br/pdf/csc/v16n6/35.pdf

7. Barbe AG, Bock, N, Derman, SHM, Felsch, M, Timmermann, L, Noack, MJ. Self-assessment of oral health care of oral helath-related quality of life among Parkinson's disease patients. Gerodontology. 2017; 34(1): 135-43. Doi: $10.1111 /$ ger.12237

8. Kayser-Jones J, Bird WF, Paul SM, Long L, Schell ES. An instrument to assess the oral health status of nursing home. Gerontologist. 1995; 35(6): 814-24. Doi: 10.1093/geront/35.6.814

9. Sanchez MAS. A dependência e suas implicações para a perda de autonomia: estudo das representações para idosos de uma unidade ambulatorial geriátrica. Textos Envelhecimento [Internet]. 2000 [citado 2020 mar 4]; 3(3): 35-54. Disponível em: https://www.rbgg.com.br/ arquivos/edicoes/TSE\%203-3.pdf

10. Gigante RL, Campos GW. S. Política de formação e educação permanente em saúde no Brasil: bases legais e referências teóricas. Trab. Educ. Saúde [Internet]. 2016 [citado 2020 mar 4]; 14(3): 74763. Disponível em: https://www.scielo.br/scielo.php?pid=S1981$77462016000300747 \&$ script=sci abstract\&tIng $=$ pt

11. Ministério da Educação (BR). Lei $9.394 / 96$ de 20 de dez. 1996: estabelece as Diretrizes e Bases da Educação Nacional. Parecer $n^{\circ}$ CNE/CES 1300/01 de 06 de novembro de 2001. Institui as Diretrizes Curriculares Nacionais dos Cursos de Farmácia e Odontologia [Internet]. Brasília: Ministério da Educação; 2001 [citado 2020 mar 4]. Disponível em: http://portal.mec.gov.br/cne/arquivos/pdf/CES1300.pdf

12. Brasil. Conselho Estadual de Educação. Deliberação CCE $n^{\circ} 378$ de 02 de junho de 2020. Define as Diretrizes Curriculares Estaduais para o Curso Técnico de Enfermagem no âmbito do Estado do Rio de Janeiro [Internet]. Rio de Janeiro: Diário Oficial do Estado do Rio de Janeiro. 2020 [citado 2020 mar 4] jun. 4; Capítulo V. p. 9. Disponível em: http://rj.corens.portalcofen.gov.br/wp-content/ uploads/2020/06/Delibera\%C3\%A7\%C3\%A3o.CEE_.378.2020_ DIRETRIZES.T\%C3\%89CNICO.ENFERMAGEM.pdf

13. Rocha DA, Miranda AF. Atendimento odontológico domiciliar aos 
idosos: uma necessidade na prática multidisciplinar em saúde: revisão de literatura. Rev bras geriatra gerontol. [Internet]. 2013 [citado 2020 mar 4]; 16(1): 181-9. Disponível em: https://www.scielo.br/pdf/rbgg/ v16n1/a18v16n1.pdf

14. Rosa LB, Zuccolatto MCC, Bataglion C, Coronatto EAS. Odontogeriatria: a saúde bucal na terceira idade. RFO UPF, 2008; 13(2): 82-6. Doi: https://doi.org/10.5335/rfo.v13i2.599

\section{HOW TO CITE}

do Carmo RF. Covid-19 vaccination in 2021 and future challenges. Revista Portal: Saúde e Sociedade, 6 (unique):e02106051. DOI:10.28998/rpss. e02106051.

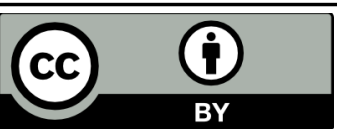

This is an Open Access article distributed under the therms of the Creative Commons Attribution License, which permits unrestricted use, distribution and reproduction in any medium, provided the original work is properly cited. 